\title{
References
}

Haughton, S. 1862: On the fossils brought home from the Arctic regions in 1859, by Captain Sir F. L. M'Clintock. J. R. Dublin Soc., July \& Oct. 1860, 53-58.

Park, I., Clarke, D. B., Johnson, J. \& Keen, M. J. 1971: Seaward extension of the West Greenland Tertiary volcanic province. Earth Planet. Sci. Lett. 10, 235-238.

Ross, D. I. \& Henderson, G., 1973: New geophysical data on the continental shelf of central and northern West Greenland. Can. J. Earth Sci. 10, 485-497.

\section{GEOLOGICAL AND GEOPHYSICAL WORK IN THE NÚGSSUAQ-DISKO REGION, CENTRAL WEST GREENLAND}

\section{Gilroy Henderson}

During the summer the geological and geophysical work on Cretaceous-Tertiary sedimentary and volcanic rocks of central West Greenland embarked upon in 1971 (see Henderson, 1972), was continued. This programme ran concurrently with offshore geophysical work (see Denham, this report), the object of the combined investigations being to study in detail the sedimentary and volcanic rocks of the entire area. With the interest in the petroleum potential of the West Greenland continental shelf continuing unabated, the only area where the Cretaceous-Tertiary rocks are exposed is clearly of considerable economic as well as academic interest.

As in 1971 three main groups participated in the work on land: a field mapping group, a geophysical group and a drilling group. A team of eight people from outside Greenland, comprising three geologists, two geophysicists, two technicians and one assistant worked in the area, and were ably assisted by Greenlanders from Niaqornat. The expedition was supported by the GGU ship "K. J. V. Steenstrup", with Andreas Viöstein as skipper.

\section{Field mapping group}

A party led by A. K. Pedersen (Univ. of Copenhagen) extended the area already mapped in detail to include north-west Disko. The Tertiary volcanic sequence in this area comprises the top of the olivine basalts from the lower lava formation and about $1.8 \mathrm{~km}$ of predominantly feldspar-porphyritic basalts from the upper lava formation.

The outermost 7-8 $\mathrm{km}$ along the west coast of Disko is very extensively faulted. The lavas strike N-S and dip west, the amount of dip increasing westwards from less than $10^{\circ}$ to $35-40^{\circ}$. The presence in the upper lava formation of a marker sequence dominated by highly sediment-contaminated lavas and tuffs enabled correlation to be made across the faults. The faults have resulted in numerous re- 
petitions within the volcanic sequence and the apparent thickness of the westwarddipping lavas in this area is considerably greater than the actual thickness.

The last three weeks were spent in north-eastern Disko where the zone covering the uppermost sediments and lowermost volcanic rocks was studied. In the Qutdligssat area the Tertiary sediments and volcanic rocks interfinger with each other in the boundary zone. In the area north of Mudderbugten there are thick sills in the sediments.

The writer and E. J. Schiener spent July examining sedimentary sections and the base of the volcanic sequence on the north coast of Nûgssuaq. The Santonian-Campanian sediments flanking the Itivdle valley were mapped and sampled in detail, partly to provide the maximum possible surface control for the geophysical work. The dark-grey, often silty shales here have a considerable content of organic material. Sandstone bands are common, but have a poor porosity. Cross bedding indicates that the source of the sediments was south-west of this area. Due east of the valley the base of the volcanic sequence comprises $15 \mathrm{~m}$ of rather thinly layered tuffs, breccias and lava flows.

In the area south of Niaqorssuaq, $6 \mathrm{~km}$ east of Niaqornat, the lower part of the volcanic sequence is unusually thick. The lowest rocks are mainly greenish, extensively altered ultrabasic pillow breccias and flows, but brown pillow breccias are also present. Due south of Niaqorssuaq the volcanic rocks rest uncomformably on Danian sediments, but in much of the area the contact is faulted. There is evidence of considerable disturbance of the lowest volcanic rocks during the deposition of the pile.

During August E. J. Schiener continued the examination and sampling of sedimentary sequences, working along parts of the south coast of Nûgssuaq and the north and east coasts of Disko. The evidence in the area seen points to sedimentation under shallow-water conditions, the depositional environment for much of the sequence being interpreted as that of a wide flat-topped delta with at times strong fresh-water influence.

Brief visits were again paid by $T$. Jürgensen to the fossiliferous locality at Marrait kitdlitt (Rosenkrantz, 1970) to collect further samples for work on the bryozoan fauna.

\section{Geophysical group}

A group led by J. W. Elder (Univ. of Manchester) undertook geophysical work in the area bounded by Ubekendt Ejland, Ikorfat and Hareøen. The main objective was to determine the structure and thickness of the sediments in the western Nûgssuaq area using explosion reflection seismic techniques.

The work was accomplished using equipment assembled at Univ. of Manchester from commercially available items. Most attention was paid to obtaining additional information on the Tuperssuartâ area, at the north-eastern end of the Itivdle val- 
ley, but field work was also undertaken during part of August in the south-western end of the valley.

In addition to reflection work using the new equipment, long-range and medium-range refraction shooting was undertaken. Gravity, magnetic and microseismic measurements were also made.

No detailed results from the survey are yet available.

\section{Drilling group}

A group led by $H$. Jørgensen undertook a drilling programme using a Craelius Prosper 25 core drill belonging to the Danish Atomic Energy Commission, Ris $\phi$. Difficulties encountered during the 1971 drilling programme were largely mechanical or due to lack of experience in drilling in such rocks in a permafrost area. With a new water pump and with the 1971 experience to go on, it was hoped that a successful programme could be carried out in 1972.

Drilling was undertaken at Tuperssuartâ, $7 \mathrm{~km}$ west of Niaqornat, at Tuperssussat, close to Niaqornat, at Niaqorssuaq, $6 \mathrm{~km}$ east of Niaqornat, on the coast $5 \mathrm{~km}$ east of Niaqorssuaq and the south-west end of the Itivdle valley.

As in 1971, the programme was beset with difficulties. Some core was recovered from the first, third and fourth of the localities mentioned, but the total recovered during the summer was very disappointing.

\section{References}

Henderson, G. 1972: Geological and geophysical work in central West Greenland. Rapp. Gronlands geol. Unders. 45, 15-20.

Rosenkrantz, A.: 1970: Marine Upper Cretaceous and lowermost Tertiary deposits in West Greenland. Bull. geol. Soc. Denmark 19, 406-453.

\section{INVESTIGATIONS OF QUATERNARY GEOLOGY IN THE AREA SOUTH OF DISKO BUGT, CENTRAL WEST GREENLAND}

\section{Joakim J. Donner}

During the summer an area between latitudes $68^{\circ} 30^{\prime}$ and $68^{\circ} 40^{\prime} \mathrm{N}$ on the west coast was investigated, including the islands south of Sarqardlip nunâ in the west and the islands and the mainland in Sydostbugten and Orpigsôq in the east. The work concerned a description of marine Quaternary deposits and the collection of shell samples from these deposits for radiocarbon dating. 